\title{
The Effect of Employee Empowerment, Organizational Justice, Conflict, and Work Motivation on Employee Performance (Case Study of Bank Mandiri Indonesia)
}

\author{
Dian Suprapto and Aslam Mei Nur Widigdo
}

\section{ABSTRACT}

This study aims to analyze a impact empowerment of employees, organizational justice, conflict and work motivation on employee performance through case studies Mandiri Branch Office (KCP) Social Security Bank in Jakarta, Indonesia. This study adopted a causal research design and data collection methods by conducting a questionnaire survey of 41 respondents en. The sampling technique is intended is a sampling technique is saturated. The analytical tool intended is SPSS version 21. The results show that some employee authorization, organizational justice, and work motivation are related to impact positively $d$ 's significant to employees performance. At the same time, conflict has a partial negative impact on employee performance and is not significant. In addition, employee empowerment, organizational justice, conflict and work motivation also have a significant impact on employee performance.

Keywords: Employee Empowerment, Organizational Justice, Conflict, Work Motivation, Employee Performance.

\section{INTRODUCTION}

In terms of company assets, PT. Bank Mandiri (Persero), Tbk is one of the largest banks in Indonesia. Bank Mandiri was established on October 2, 1998, as a banking restructuring plan implemented by the Indonesian government, consisting of four state-owned banks, namely Bank Bumi Daya, Bank Dagang Negara, Bank Export Import Indonesia and Bank Pembangunan Indonesia.

Bank Mandiri is always required to be able to improve services and healthy credit growth. But in reality, the performance of employees at Bank Mandiri Sub-Branch Office (KCP) Jakarta Jamsostek Building is still not optimal. This can be seen from the sales data of Mandiri Multipurpose Loans in January-June 2020 which still did not meet the target.

TABLE I: MANDIRI MULTIPURPOSE CREDIT SALES DATA BANK MANDIRI KCP JAKARTA JAMSOSTEK BUILDING

\begin{tabular}{ccccc}
\hline Month & \multicolumn{2}{c}{ Sale } & $\begin{array}{c}\text { Percentage } \\
\%\end{array}$ & Information \\
\cline { 2 - 3 }$(2020)$ & Target & Realization & $93 \%$ & Not achieved \\
\hline January & $8 \mathrm{M}$ & $7.4 \mathrm{M}$ & $109 \%$ & Achieved \\
February & $8 \mathrm{M}$ & $8.7 \mathrm{M}$ & $109 \%$ & Not achieved \\
March & $8 \mathrm{M}$ & $7 \mathrm{M}$ & $88 \%$ & Not achieved \\
April & $8 \mathrm{M}$ & $5.4 \mathrm{M}$ & $68 \%$ & Not achieved \\
May & $8 \mathrm{M}$ & $4.1 \mathrm{M}$ & $51 \%$ & Not achieved \\
June & $8 \mathrm{M}$ & $4.8 \mathrm{M}$ & $60 \%$ &
\end{tabular}

Source: Bank Mandiri KCP Jakarta Jamsostek Building 2020.

Based on Table I, the achievement of the sales target was only in February, which was $109 \%$. Meanwhile, in January, March, April, May, and June, the realization of sales did not reach the target.
Submitted : September 15,2021

Published : October 18, 2021

ISSN: $2507-1076$

DOI: $10.24018 /$ ejbmr.2021.6.5.1112

\section{Dian Suprapto}

Master of Management, Mercu Buana

University, Jakarta, Indonesia.

(e-mail: dsuprapto4@gmail.com )

Aslam Mei Nur Widigdo

Master of Management, Mercu Buana

University, Jakarta, Indonesia.

(e-mail: aslam.mei@mercubuana.ac.id)

*Corresponding Author
In order to find out the indications of factors that affect employee performance, a pre-survey was conducted to 20 employees of Bank Mandiri KCP Jakarta Jamsostek Building. The results of the pre-survey found 4 factors that were thought to have the most influence on employee performance, namely employee empowerment, organizational justice, conflict, and work motivation.

Based on the above research, the formulation of the problem of research this is:

1. Does employee authorization have an impact on employee performance at Bank Mandiri KCP Jakarta Jamsostek Building?

2. Does organizational justice have an impact on employee performance at Bank Mandiri KCP Jakarta Jamsostek Building?

3. Will the conflict affect the performance of the employees of Bank Mandiri KCP Jamsostek Jakarta Building?

4. Does work motivation have an impact on employee performance at the Jamsostek Building at Bank Mandiri KCP Jakarta?

5. Do employee empowerment, organizational justice, conflict and work motivation have an impact on employee performance at Bank Mandiri KCP Jakarta Jamsostek Building?

\section{LIBRARY RESEARCH AND HYPOTHESIS DEVELOPMENT}

Khan in [1] states that employee empowerment is a continuous interpersonal relationship to build trust between 
employees and management. The dimensions of employee empowerment according to Khan in [1], that is, employee participation, authorization, appreciation, recognition, open communication, and credibility.

The theory that links empowerment with employee performance is the theory put forward by Khan in [2] which says Empowerment increases self-confidence to do something, which is a belief that has never existed before, so that through empowerment it will improve organizational and individual performance and can provide talent. they sec fig full. In line with the results of research conducted by [1] states that employee empowerment has a positive and significant impact on employee performance. It means, the better the employee empowerment applied in the organization, the higher the employee's performance.

Based on the above discussion, a hypothesis can be made:

$H_{1}$ : Employee empowerment has a positive and significant impact on employee performance.

Organizational justice based on Colquitt, LePine, and Wesson in [3] says organizational justice is a person's fair view of decisions made by his superiors. Employees who get fair treatment will feel satisfied and continue to improve their performance in a better direction. The dimensions of organizational justice according to Colquit in [3] are distributive justice, procedural justice, and interactional justice.

The theory that connects the concept of organizational justice with employee performance is the theory proposed by Zapata-Phelan, Colquitt, Scott, and Livingston in [4] which says that organizational justice promotes the company's environment and employee attitudes towards their work commitment and is motivated for their performance. The results of research conducted by [3] and [4] state that organizational justice has a positive and significant impact on employee performance. This means that the better the organizational justice, the higher the employee's performance.

Based on the discussion above, the following hypotheses can be made:

$\mathrm{H}_{2}$ : Organizational justice has a positive and significant impact on employee performance.

Robbins in [5] explains that work conflict is a process that begins when one party believes that another party has or will have a negative impact on the organization or company that has attracted the attention of the first party. The dimensions of conflict according to Robbins in [5], are functional conflict and dysfunctional conflict.

Robbins in [5] states that conflict may not bring death to the company, but if the conflict is allowed to continue without being resolved, it will reduce employee performance. In harmony with $\mathrm{h}$ as il study earlier conducted [11] which state that conflict has a negative and significant impact on employee performance. This means that the lower the conflict, the higher the employee's performance. However, in contrast to the results of research by [9], work conflict has a negative and insignificant impact on employee performance.

Based on the above discussion, a hypothesis can be made:

$H_{3}$ : Conflict has a negative and significant impact on employee performance.

According to [6] Motivation is a state or energy that excites the employee-directed or aimed to achieve organizational goals the company. Herzberg in [6] states that there are two dimensions of work motivation, namely intrinsic and extrinsic motivation.

David Mc Celland in [6] stating There is a positive relationship in between achievement motivation and work performance. In line with the results of previous research conducted by [10] and [7] stated motivation air work impacts positively and significantly to the performance of the employee. It means, if the work motivation is high, the employee 's performance is also high.

Based on the above discussion, a hypothesis can be made:

$\mathrm{H}_{4}$ : Work motivation has a positive and significant impact on employee performance.

According to [6] Employee performance is the result of qualitative and quantitative work achieved by employees in carrying out their duties in accordance with the tasks assigned to them. Mangkunegara in [7] employee performance is measured by 4 dimensions, namely quality of work, quantity of work, execution of duties, and responsibilities. According to [6] if it is supported by personal attributes, work effort and organizational support, employee performance will be achieved. This includes employee empowerment, organizational justice, conflict, and work motivation.

Based on the above discussion, a hypothesis can be made:

H5: Employee empowerment, organizational justice, conflict, and work motivation have a significant impact on employee performance.

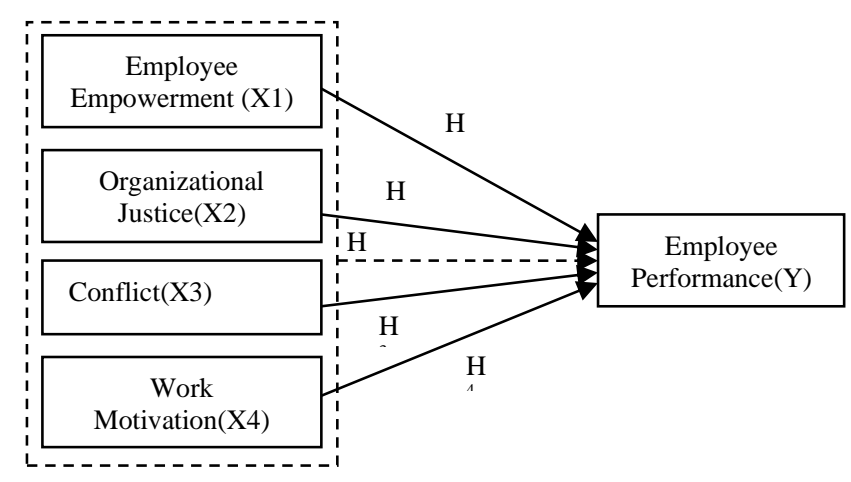

Fig. 1. Framework.

\section{RESEARCH METHOD}

Design studies are devoted to the study of this is causal research. Causal research is defined as a causal relationship, where the independent variable affects the dependent variable [8].

The population in this study were all 41 employees of Bank Mandiri KCP Jakarta Jamsostek Building, and the sample selection used a saturated sampling technique (census).

The technique of collecting data is through distributing questionnaires to respondents, which aims to analyze respondents' answers about the impact of employee empowerment, organizational justice, conflict, and work motivation on employee performance.

After testing the validity of the data, the data reliability test, and classical assumption by using SPSS version 21 , then $\mathrm{m}$ etode main used to clicking the data analysis is linear regression analysis. According to [8] a nalisis a multiple linear regression analysis in order to measure the impact of a ntara independent variable on the dependent variable. 


\section{RESEARCH RESULTS AND DISCUSSION}

A. Research Results

1) Multiple Linear Regression Test Results

TABLE II: MULTIPLE LINEAR REGRESSION TEST RESULTS

\begin{tabular}{ccccc}
\hline \multirow{2}{*}{ Model } & \multicolumn{2}{c}{$\begin{array}{c}\text { Unstandardized } \\
\text { Coefficients }\end{array}$} & $\begin{array}{c}\text { Standardized } \\
\text { Coefficients }\end{array}$ \\
\cline { 3 - 5 } & (Constant) & 1,469 & 0,492 & Beta \\
\hline \multirow{2}{*}{$1 \quad$ Employee Empowerment } & 0,200 & 0,096 & 0,219 \\
& Organizational Justice & 0,476 & 0,117 & 0,490 \\
& Conflict & $-0,524$ & 0,125 & $-0,388$ \\
& Work motivation & 0,229 & 0,110 & 0,232 \\
\hline \hline
\end{tabular}

Source: SPSS output version 21, 2021.

From the results of multiple linear regression, it can be seen that the regression equation is:

$$
Y=1.469+0.200 \times 1+0.476 \times 2-0.524 X 3+0.229 X 4
$$

Based on the regression equation, the interpretation can be explained, namely:

1. Constants of 1,469 which is a constant, meaning that if the empowerment of employees, organizational justice, conflict, and work motivation con booth, then the performance of employees amounted to 1,469 .

2. The regression coefficient miscellany bell employee empowerment of 0.200 and Air impact positively, it means that if the variable employee empowerment increases, the impact of her against kinefw employees will be increased by 0.200 assuming other variables remain valuable.

3. The regression coefficient variabel organizational justice at 0.476 and Air impact positively, it means that if justice organization increases, the impact by the performance of employees will be increased by 0.476 assuming other variables remain valuable.

4. Koefisien conflict regression of -0.524 and air impact is negative, it means that if conflict increase the impact of its terha dap performance of employees will decrease by -0.524 assuming other variables remain valuable.

5. The coefficient regression work motivation at 0.229 and air impacts positively, it means that if the variable motivation to $\mathrm{fw}$ increases, the impact of $\mathrm{n}$ yes to karyawa performance will increase by 0.229 assuming other variables remain valuable.

\section{2) Determination Test Results (R2)}

TABLE III: DETERMINATION TEST RESULTS

\begin{tabular}{ccccc}
\hline \hline Model & $\mathrm{R}$ & R Square & $\begin{array}{c}\text { Adjusted R } \\
\text { Square }\end{array}$ & $\begin{array}{c}\text { Std. Error of the } \\
\text { Estimate }\end{array}$ \\
\hline 1 & $0,840^{\text {a }}$ & 0,705 & 0,673 & 0,314 \\
\hline \hline
\end{tabular}

a. Predictors: (constant), work motivation, conflict, employee empowerment, organizational justice.

b. Dependent variable: employee performance.

Source: SPSS output version 21, 2021

From the results of the determination test the value of multiple correlation is 0.840 while the value of R Square (R2) is 0.705 or $70.5 \%$. This shows that the percentage of the impact of the independent variable (employee empowerment, organizational justice, conflict, work motivation) on the dependent variable of employee performance is $70.5 \%$, while $29.5 \%$ is influenced by other variables not examined.

\section{3) Partial Test ( $t$ Test)}

TABLE IV: PARTIAL TEST RESUlTS

\begin{tabular}{|c|c|c|c|c|c|}
\hline \multirow{2}{*}{ Model } & \multicolumn{2}{|c|}{$\begin{array}{l}\text { Unstandardized } \\
\text { Coefficients }\end{array}$} & \multirow{2}{*}{$\begin{array}{c}\begin{array}{c}\text { Standardized } \\
\text { Coefficients }\end{array} \\
\text { Beta }\end{array}$} & \multirow{2}{*}{$\mathrm{t}$} & \multirow{2}{*}{ Sig } \\
\hline & $\mathrm{B}$ & $\begin{array}{l}\text { Std. } \\
\text { Error }\end{array}$ & & & \\
\hline (Constant) & 1,469 & 0,492 & & 2,983 & 0,005 \\
\hline $\begin{array}{c}\text { Employee } \\
\text { Empowerment }\end{array}$ & 0,200 & 0,096 & 0,219 & 2,090 & 0,044 \\
\hline $\begin{array}{l}\text { Organizational } \\
\text { Justice }\end{array}$ & 0,476 & 0,117 & 0,490 & 4.052 & 0,000 \\
\hline Conflict & $-0,524$ & 0,125 & $-0,388$ & $-4,209$ & 0,000 \\
\hline Work motivation & 0,229 & 0,110 & 0,232 & 2,082 & 0,44 \\
\hline
\end{tabular}

The result of the partial test is that the $t$ coun of employee empowerment is 2.090. On the degrees of freedom $(\mathrm{df})=\mathrm{n}$ $\mathrm{k}=41-4=37$ with $\alpha=5 \%$, obtained $\mathrm{t}_{\text {table }}$ amounted to 2.026 . Because $t_{\text {arithmetic }} 2.090>t_{\text {table }} 2.026$ then Ho is rejected, meaning that there is a significant impact between employee empowerment on employee performance. Impact $\mathrm{k}$ eadilan organization on the performance of employees obtained $t$ coun 4,052> $\mathrm{t}_{\text {able }} 2.026$ then Ho is rejected, it means that there are impacts significantly between organizational justice against kine fw employees. The impact of conflict on employee performance is obtained $\mathrm{t}_{\text {count }}-4.209>\mathrm{t}_{\text {table }}-2.026$ then Ho received, meaning no no impact significantly on the conflict on employee performance. The impact of work motivation on employee performance is obtained $\mathrm{t}_{\text {arithmetic }} 2.082>\mathrm{t}$ table 2.026 then Ho is rejected, meaning that there is a significant impact between work motivation on employee performance.

\section{4) Simultaneous Test (F Test)}

With the test calculations simultaneously obtained nilai profitability $(\mathrm{sig})=0,000$ while the value of $\mathrm{F}_{\text {table }}$ at significance level of $5 \%(\mathrm{df})=\mathrm{n} \mathrm{k}-1=41-4-1=36$ obtained $\mathrm{F}$ table of 2.63. Because $\mathrm{F}$ count $21.537>\mathrm{F}_{\text {table }} 2.63$ then $\mathrm{Ho}$ is rejected, meaning that employee empowerment, organizational justice, conflict, and work motivation have a significant impact on employee performance.

TABLE V: SimULTANEOUS TEST RESUlTS

\begin{tabular}{ccccccc}
\hline \hline \multirow{2}{*}{ ModelR } & $\begin{array}{c}\text { Sum of } \\
\text { Squares }\end{array}$ & D f & $\begin{array}{c}\text { Mean } \\
\text { Square }\end{array}$ & F & Sig \\
\hline \hline 1 & Regression & 8,488 & 4 & 2,122 & 21.537 & $0,000^{\mathrm{b}}$ \\
& Residual & 3,547 & 36 & 0.099 & & \\
& Total & 12,035 & 40 & & & \\
\hline \hline
\end{tabular}

a. Dependent Variable: Employee performance.

b. Predictors (Constant): work motivation, conflict, employee empowerment, organizational justice.

Source: Output SPSS version 21, 2021

\section{5) Inter-Dimensional Correlation Test}

Based on the results of the correlation test between dimensions, the strongest correlation between dimensions between the dimensions of procedural justice and the dimensions of work quality is 0.728 . 
TABLE VI: CORRELATION TEST RESULTS BETWEEN DIMENSIONS

\begin{tabular}{|c|c|c|c|c|c|}
\hline \multirow[b]{2}{*}{ Variable } & \multirow[b]{2}{*}{ Dimension } & \multicolumn{4}{|c|}{ Employee performance } \\
\hline & & $\begin{array}{l}\text { Quality } \\
\text { of Work }\end{array}$ & $\begin{array}{c}\text { Job } \\
\text { Quantity }\end{array}$ & $\begin{array}{c}\text { Task } \\
\text { Implementation }\end{array}$ & Responsibility \\
\hline \multirow{6}{*}{$\begin{array}{c}\text { Employee } \\
\text { Empowerm } \\
\text { ent }\end{array}$} & $\begin{array}{c}\text { Employee } \\
\text { Engagement }\end{array}$ & $0.463 * *$ & $0.531 * *$ & $0.519 * *$ & $0.402 * *$ \\
\hline & Delegation & 0.214 & $0.370 *$ & $0.325^{*}$ & $0.340 *$ \\
\hline & Award & 0.23 & 0.16 & 0.249 & 0.169 \\
\hline & Confession & 0.192 & 0.249 & $0.314 *$ & $0.446^{* *}$ \\
\hline & Open Communication & 0.181 & $0.315^{*}$ & 0.174 & 0.293 \\
\hline & Credibility & 0.254 & 0.246 & 0.142 & 0.246 \\
\hline \multirow{3}{*}{$\begin{array}{l}\text { Organizatio } \\
\text { nal Justice }\end{array}$} & Distributive Justice & $0.645 * *$ & $0.533 * *$ & $0.532 * *$ & $0.369^{*}$ \\
\hline & Procedural Justice & $0.728 * *$ & $0.717 * *$ & $0.638 * *$ & $0.610^{* *}$ \\
\hline & Interactional Justice & $0.531 * *$ & $0.571 * *$ & $0.569 * *$ & $0.456^{* *} *$ \\
\hline \multirow{2}{*}{ Conflict } & Functional Conflict & -0.053 & -0.138 & -0.112 & -0.224 \\
\hline & Dysfunctional Conflict & $-0.315^{*}$ & -0.223 & $-0.373^{*}$ & -0.272 \\
\hline \multirow{2}{*}{$\begin{array}{c}\text { Work } \\
\text { motivation }\end{array}$} & Intrinsic Motivation & $0.443 * *$ & $0.512 * *$ & $0.468 * *$ & $0.488 * *$ \\
\hline & Extrinsic Motivation & $0.530 * *$ & $0.479 * *$ & $0.514 * *$ & $0.458 * *$ \\
\hline
\end{tabular}

Sumber: Output SPSS version 21, 2021.

\section{B. Discussion}

\section{1) Impact of Employee Empowerment on Employee Performance}

The results of the study show that several authorized employees have a positive and significant impact on employee performance. Means how rejected. That is, the better the employee's authorization applied in the organization, the higher the employee's performance. The results of this study prove the theory put forward by Khan in [2] that authorization increases self-confidence to do things that have never been done before, and then through empowerment will improve organizational and individual performance and can carry out their talents fully.

\section{2) Impact of Organizational Justice on Employee Performance}

The research shows that organizational justice has a positive and significant impact on employee performance. Means Ho is rejected. This means that the better the organizational justice applied in an organization, the higher the employee's performance. The results of the study prove the theory proposed Zapata-Phelan, Colquitt, Scott, and Livingston in [4] says that justice organization promoting corporate environment and employee attitudes toward their work and motivated commitment to performance $\mathrm{m}$ hey.

\section{3) Impact of Conflict on Employee Performance}

The results of the study show that the conflict has a partial negative impact on employee performance and is not significant. This means that Ho is accepted. This means that the higher the conflict in the workplace, it does not necessarily reduce employee performance. Based on the results of the correlation test between dimensions, this is because the relationship between the dimensions of functional conflict and the dimensions of work quality is very weak. This means that although employees have low functional conflict, they do not necessarily improve employee performance. [9] The results of previous studies confirm the results of this study, which shows that work conflict has a negative and insignificant impact on employee performance.

\section{4) Impact of Work Motivation on Employee Performance}

Results of the study show that job motivation ber impact positively and significantly to the performance of an employee. Means how rejected. In other words, the higher morale then more and more high-performance employees are.
The results of the study proved that theory in David McLand [6] shows that there is a positive relationship in between achievement motivation and performance achievement. The results of this study support the results of previous studies [7] and [10] which show that work motivation has a positive and significant impact on employee performance.

5) Impact of Employee Empowerment, Organizational Justice, Conflict, and Work Motivation on Employee Performance

The results showed that employee empowerment, organizational justice, conflict, and work motivation simultaneously had a positive and significant impact on employee performance. Means how rejected. That is, if employee authorization and organizational impartiality applied in the organization are good, the level of conflict is low, and is supported by high work motivation, then employee performance is also high. The results of this study prove the theory [6] that if employee performance is supported by personal attributes, work effort, and organizational support, it will be realized. These include employee empowerment, organizational justice, conflict, and work motivation.

\section{6) Managerial Implications}

Based on the results of the correlation analysis between dimensions where there is the strongest correlation between organizational justice variables on the procedural justice dimension and employee performance variables on the dimensions of work quality and work quantity dimensions. Given the strongest correlation, the company should pay attention to procedural fairness such as all job decisions are consistently assigned to employees and each employee or work unit is asked to provide suggestions in making company decisions, so by doing this it can improve the quality of work such that employees are able to work carefully and agile so as to achieve the quality standards of work set by the company. In addition, it can increase the quantity of work such as encouraging employees to achieve work targets, being able to exceed the given workload, and achieving time efficiency at work. 


\section{Conclusions And Suggestions}

\section{A. Conclusion}

Based on the research and discussion above, it can be in a knot $\mathrm{k}$ 's research results as follows:

1. Employee empowerment has a positive and significant impact on employee performance at PT. Bank Mandiri (Persero) KCP Jakarta Jamsostek Building.

2. Organizational justice has a positive and significant impact on employee performance at PT. Bank Mandiri (Persero) KCP Jakarta Jamsostek Building.

3. Conflict has a negative and insignificant impact on employee performance at PT. Bank Mandiri (Persero) KCP Jakarta Jamsostek Building.

4. Work motivation has a positive and significant impact on employee performance at PT. Bank Mandiri (Persero) KCP Jakarta Jamsostek Building.

5. Employee empowerment, organizational justice, conflict, and work motivation have a significant impact on employee performance at PT. Bank Mandiri (Persero) KCP Jakarta Jamsostek Building.

\section{B. Suggestion}

From the results of the research that has been done, suggestions that can be submitted to:

\section{Organization}

Each employee or work unit is asked to provide suggestions in making company decisions, so that employees will feel valued which will lead to an increase in the quality of work. This can be done through the company asking for opinions from employees/work units through discussion forums or by distributing online questionnaires for company decision making.

\section{Next Research}

In connection ket research has erbatasan the percentage impact of independent variables (employee empowerment, organizational justice, conflict, motivation) to the dependent variable (performance of employees) amounted to $70.5 \%$, while $29.5 \%$ on the impact $i$ by other variables that are not researched, disarankan further research can do research by adding some other independent variables such as organizational culture, compensation, social intelligence and emotional intelligence, physical work environment, and transformational leadership where these variables can also add hasi 1 more widely associated with factors which determines employee performance.

\section{REFERENCE}

[1] Nurlina, "Impact of Employee Empowerment and Compensation on Employee Performance at PT. BNI Panakkukang Branch," Journal of Economix, vol. 8. No. 1, June 2020. STIMI YAPMI, Makassar.

[2] Wibowo, "Change management," Third Edition. PT. Press Eagle. Jakarta, 2012.

[3] M. Z. Iqbal, M. Rehan, A. Fatima, N. Nawab, "The Impact of Organizational Justice on Employee Performance in Public Sector Organization of Pakistan," International Journal of Economics \& Management Sciencesc, Institute of Information Technology, Wah Campus, Pakistan, 2017.

[4] A. Zahid, M. Zahra, M. Amjad, R. Mukhtar, M. Hamzah, R. Athar, "Influence of Organizational Conflict Management and Procedural Justice on Employee Performance in Academia of Pakistan," Journal of Research in Psychology, vol. 1, no. 2, pp. 16-19, 2019. University, Rawalpindi, Pakistan.
[5] S. I. Wahjono, "Organizational behavior," Graha Ilmu Publisher. Yogyakarta, 2010.

[6] A. P. Mangkunegara, "HR Performance Evaluation,. PT. Aditama Refika. Bandung, 2019.

[7] F. Ghiyats, I. N. Aulia, "The Effect of Competence and Motivation of Employee Performance with Organizational Commitment as Intervening Variables in PT. Indonesian Creative Maleo," IJISRT, vol. 5, Issue 7, July-2020. Master of Management, Mercubuana University, Jakarta, Indonesia.

[8] Sugiyono, Statistics to Research. Alphabet. Bandung, 2014.

[9] N. Solatiah Siti, F. L. Muhammad, "The Effect Of Burnout, Leadership Style And Work Conflict On Civil Servants' Performance In SubDistricts Throughout The City of Mataram, Indonesia," Eurasia: Economics \& Business, vol. 6, no. 24, June 2019. Master's Program in Management. University of Mataram, Indonesia.

[10] R. R. Soulisa, Kasmir, U. T. Handiman, "The Influence of Compensation, Leadership and Motivation on Employee Performance," International Journal of Business Marketing and Management (IJBMM), Mercubuana University, Indonesia, 2020.

[11] R. B. Kurniawan, R. A. Sularso, P. Titisari, "The Effect of work conflict and job stress on employees performance with organizational commitment as intervening variable," Journal Management, vol. 6, No. 01, 2018. Master's Program in Management. University of Jember, Indonesia. 